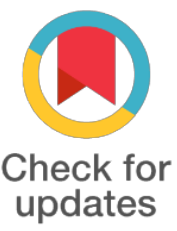

${ }^{*}$ For correspondence:

mejpaul@gmail.com

Competing interests: The authors declare that no competing interests exist.

Received: 2017-04-29

Accepted: 2017-05-14

Published: 2017-09-05

Copyright The Author(s) 2017. This article is published with open access by BioMedPress (BMP).

This article is distributed under the terms of the Creative Commons Attribution License (CC-BY 4.0) which permits any use, distribution, and reproduction in any medium, provided the original author(s) and the source are credited.

\section{Cytotoxicity of Corchorus olitorius Linn. aqueous leaf extract against human carcinoma cells}

\author{
John Paul Tosoc, Olga M. Nuñeza, Mylene M. Uy, WTPSK Senarath \\ Department of Biological Sciences, College of Science and Mathematics, Mindanao State \\ University - Iligan Institute of Technology
}

\section{Abstract}

C. olitorius are used as herbal medicine and eaten as vegetable by local people in Philippines. The T'boli tribe commonly uses this plant to treat common illnesses such as pimples, wounds, boils, and inflammations. According to studies, the leaves of $\mathrm{C}$. olitorius has properties to treat demulcent, diuretic, febrifuge, chronic cystitis, dysuria and even tumor. The aim of this study is to evaluate the cytotoxicity properties of the crude aqueous extract of $C$. olitorius leaf against colon (HCT116), breast (MCF-7), and liver (HepG2) carcinoma cell-lines using the MTT cell proliferation assay. The results showed that the aqueous extract has potential cytotoxicity activity against the three-carcinoma cell-lines. The aqueous extract was most bioactive in the colon carcinoma cell-line (HCT116) with cell viability percentage of 23.53 and 32.48 in 100 and 10 $\mu \mathrm{g} / \mathrm{mL}$, respectively. It was then followed by the breast carcinoma cell-line (MCF7) with cell viability percentage of 16.23 and 30.25 in 100 and $10 \mu \mathrm{g} / \mathrm{mL}$, respectively. The extract was least but still bioactive in the liver carcinoma cell-line (HepG2) with cell viability percentage of 91.20 and 132.76 in 100 and $10 \mu \mathrm{g} / \mathrm{mL}$, respectively. This study illustrates the importance of toxicological screening to confirm the safety and efficacy of the medicinal plant commonly used in the traditional medicine system in the treatment and management of illnesses by the T'boli tribe in South Cotabato.

\section{Keywords}

Corchorus olitorius, Cytotoxicity, Medicine, Traditional, T’boli

Funding

DOST-ASTHRDP Scholarship Program

\title{
References
}

